
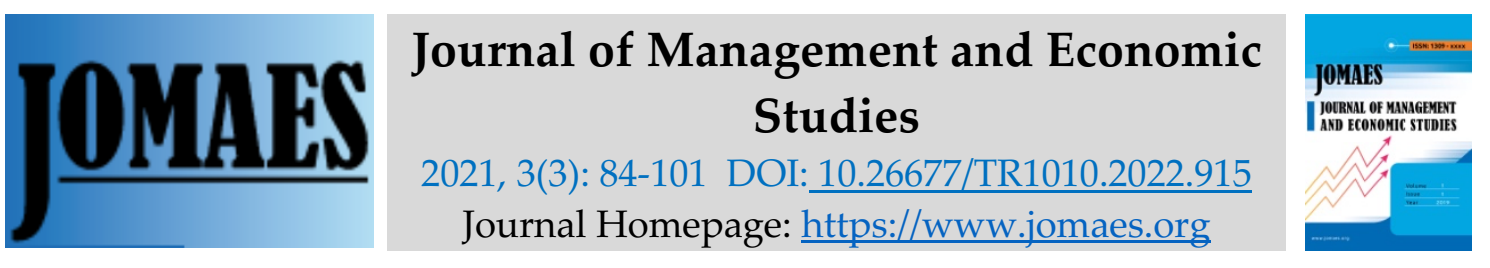

\title{
Empirical Analysis of Oil price changes on Inflation in Nigeria
}

\author{
Melemi, ABATCHA (PhD) \\ Senior Lecturer, Department of Economics, Federal University Gashua, Yobe State, Nigeria \\ 0000-0003-4210-2462)- ORCID, Melemi2@yahoo.com
}

\begin{abstract}
This study empirically analyzed the impact of oil price changes on inflation in Nigeria using monthly time series data for the period of January 1991 to April 2019. The study employed Autoregressive Distributed Lag (ARDL) Model after the result of the unit root tests revealed mixture of integrated order of the stationarity level of the variables. The ARDL results showed that in the long run, oil price exerts positive influence on the rate of inflation in Nigeria over the time which means that as oil price increases, inflation rate does increase. Also the exchange rate as part of the control variables and the lag value of the dependent variable exert positive influences on the target variable. In the short run, oil price also shows a positive relationship with the inflation rate which is in accordance with the long run result. It can therefore be concluded that, oil price changes remain one of the important inflation's influencing variables. Hence, it is recommended that curbing the increasing erratic inflation rate as a cankerworm that eats the fabric of prosperity of an economy could be done by paying good attention to the swinging nature of oil price as well as exchange rate and taking proactive actions in manipulating monetary policy tools to cushion any negative effect as a result of their outcomes in the economy.
\end{abstract}

Keywords: Oil price, Inflation, Exchange Rate, ARDL

\section{Introduction}

The impact of inflation on every economy cannot be overemphasized, it plays vital role in determining the extent of stability in an economy and it is therefore regarded to be one of the paramount factors to be taken into consideration when formulating sound macroeconomic policies. It is economically believed that low inflation impacts the economic growth negatively while high inflation affects the poor severely more than the rich in the society. Inflation rates' trend in Nigeria can be attributed to the monetization of the black gold revenue that was discovered in saleable form in the 1970's, the excess of which was 30 percent. The movement of inflation rate in Nigeria, over the years has been unsteady but empirically observed to be correlated with the pattern of the revenue generated from the black gold monetization. The fluctuating trend of inflation rates in Nigeria has caused the policy makers to always seek solutions to the problem. 
Consequently, studying the impact of macroeconomic factors such as the oil price performance on rate of inflation has implications for investors and policy makers (Corrado and Jordan 2002). The persistent increase in the general price of goods and services in the economy is traced to the increasing money supply due to the fact that growth in its real term is less than the money growth. This can be observed from the increase in money supply and some other structural factors such as; supply shocks arising from famine, unfavorable terms of trade and devaluation of currency. Furthermore, Structural Adjustment Program (SAP) introduced by the government in the late 1980's also accounted for the increase in the price level in the economy (Oyinpreye, 2017).

In furtherance, inflation rates in Nigeria have been greatly influenced by the structural changes and these changes, based on the events that occurred and their patterns, can be categorized in to four major periods over the time. Between 1974 and 1976, the first period of skyrocketed general price of goods and services was experienced; inflation rates increased by 30 percent. The pressure in the economy was attributed to the excessive oil revenue monetization coupled with the high cost of agricultural produce which is the product of drought in the Northern Nigeria and increase wage rate as a result of the Udoji commission's recommendation of 1974.

In the second period, the period between 1983 and 1985, the inflationary pressure reached 40 percent, and a very little growth in the economy was observed. The Nigerian government experienced pressure to devaluate her domestic currency from the debtor groups, International Monetary Fund given that the Nigerian government's debt had increased above 70 percent and her excess money growth was around 41 and 43 percent. In this period, the economy experienced poor external trade performance (CBN, 2006). The third period was from 1987 to 1989 when the inflation rate hovered around 35 percent. During this period, the economy experienced high inflationary pressure brought about by fiscal expansion noticed in the 1988 budget, the debt for equity swap conversion method adopted by the Government of Nigeria and the drastic contraction in monetary policy, all accounted for this change that span through to the early 1990's. Finally, the fourth period occurred between 1993 and 2000, as a result of fiscal deficit expansion which caused a 70 percent increase in the money supply with a knock-on effect on domestic credit to the private sector of the economy (CBN, 2006).

In Nigeria, a monoculture economy which depends heavily on the earnings from the crude oil exports, the persistent fluctuation of crude oil prices in the global market has been revealed to have adversely affected general performance of the economy. Crude oil price instability has been found to affect production cost of foreign firms and since Nigeria is an import-dependent economy, an increase in crude oil prices makes imported goods to be very expensive which is in turn transmitted to domestic prices by raising the general price level (Mba-Afolabi, 1999; Labys, 2006; Nwosu, 2009; Arinze, 2011; Runl, 2011; Bobai, 2012). More than ten times, the prices of crude oil were reviewed from 1990 to 2011, The adjustment in 2000 under the democratic administration gave the economy a turning point as petroleum price moved up to N30 per litre, diesel to N29 and kerosene to N27 Runl (2011). According to the government, the upward review of domestic prices of petroleum products was necessitated by the high spot market price of crude oil and the need for higher margins for the Nigerian National Petroleum Corporation (NNPC) to meet operational and capital costs. Using Philips curve framework, Hooker (1996, 2002), LeBlanc and Chinn (2004), Blanchard and Gali (2007), Valcarcel and Wohar (2013) posit that in countries such as the US, Japan, UK, Germany, France, Italy, the effect of oil prices on inflation and economic activities have dropped substantially over the time. And their major argument for declining role of oil prices are effective monetary policy responses to unanticipated shocks, less rigid labor markets and lower energy intensity of industries. Additionally, some studies have revealed an asymmetric pattern in oil price fluctuations, which means that although oil price hikes lead to a 
rise in domestic inflation even in negligible amount, on the hand, an oil price decline does not yield any conclusive results (Lown and Rich, 1997).

However, it is observed that many have researched on the topic of interest both internationally and locally but very few used advanced and more robust methodology locally hence the gap to be filled in this paper. Therefore, in this study, Autoregressive Distributed Lag Model will be used to determine the relationship between oil price and inflation in Nigeria. The structure of the study is divided into five sections which include; section one which is Introduction, section two which is literature review, section three which is methodology, section four which is analysis and interpretation, and section five which is Summary, conclusion and recommendation.

\section{Literature Review}

The relationship between oil price and inflation has caught the attention of many researchers who have employed different approaches to examining the linkages between the two variables.

Anwar, Khan, and Khan (2015) study the impact of oil price increase on persistent increase in price level in Pakistan from a period of 2002:1 to 2011:12. They employed ordinary least square (OLS) method and the result shows that there exist a positive and significant impact of oil price on inflation while exchange rate also shows a significant impact, it is however a negative relationship with inflation. Also, Malik (2016) investigate how oil price affect inflation in Pakistan with data from 1979:1 to 2014:12. He employed Augmented Phillips curve framework and the study revealed that, continuous increase in oil price have a strong relationship with inflation.

Using different methods, Živkov, Đurašković, \& Manić (2018) investigate the impact of oil price changes on inflation in Central and Eastern European countries with a monthly time -series data from January 1996 to June 2018. Using wavelet-based Markov switching approach, the study found that exchange rate does not significantly affect inflation in the process of transmission mechanism between oil price and exchange rate unless there is depreciation in the exchange rate. Similarly, Al-Eitana and Al-Zeaudb (2017) investigate the relationship between crude oil prices volatility as well as its impact on inflations in Jordan with data from 2000: to 2013:12. They used Analysis of variance (ANOVA) and the result revealed that crude oil prices account for little impact on inflation in Jordanian economy.

Using granger causality test, Rangasamy (2017) investigate how the movements in the petrol price affects inflation in South African using yearly data from January 1976 to December 2015. The result of Granger causality tests and the autoregressive distributed lag approach (ARDL) results revealed petrol price have significant impact on the level of inflation, while this is not only significant on inflation but oil price also granger causes other prices in South Africa. Also, Subhani, Hasan, Qavi, and Osman (2012) investigate the connection among crude oil price and inflation in Pakistan using annual time series-data from 1980 to 2010. The result reveals that, crude oil price granger causes inflation and inflation does not granger cause crude oil price in Pakistan for the period of study.

In the same vein, from a cross country analysis, Castro, Jiménez-Rodríguez, Poncela and Senra (2017) examine the oil price pass-through into inflation, evidence from disaggregated European data which consist of (France, Germany, Italy and Spain) using monthly time-series data from January 1996 to December 2014. Employing Granger causality tests, the result shows that the inflation responded in different pattern and magnitude with respect to various economies. While, López-Villavicencio and Pourroy (2019) evaluate the pass-through of oil price changes to consumer prices for a large sample of countries comparing countries with and without inflation targeting from 1970 to 2017. They employed State-space models and the results suggest that 
countries with inflation targeting (IT) policies have a higher oil price - inflation pass-through than countries without inflation targeting policies.

Applying vector error correction model and vector auto-regression, ALsaedi (2015) examine the association between oil prices, inflation, exchange rate and economic activities cases of GCC using monthly data from 2010 to 2014. He employed vector error correction model and the result shows that oil prices and devaluation have strongly significant positive effect on economic activity. Inflation also has positive effect on economic activity. Also, Sibanda, Hove and Murwirapachena (2015) investigate how crude oil prices as well as exchange rate dictates inflation expectations in South Africa with data 2002: to 2013:3. The study employed Vector errorcorrection model (VECM) and the result shows that crude oil prices and exchange rate have significant impact on inflation expectations in South Africa with high rate of adjustment back to equilibrium in the case of any disequilibrium.

Conflitti and Luciani (2017) examine oil price pass-through into core inflation in the U.S and Euro area using yearly time-series data from 1984 to 2016. Vector Auto-Regression (VAR) model was employed and result shows that the oil price passes through core inflation only via its effect on the whole economy. While, Bhattacharya and Bhattacharyya (2001) examine how increase in oil prices affect inflation and output in India for the period of 1994:4 to 2000:12. The Granger causality result thus seems to be bidirectional, while inflation responded positively to one per cent shocks in oil prices after the period of seven month of the shocks as shown from impulse response result.

In another sets of cross countries analysis, Bala and Chin (2018) investigate the linear relationship and impact between oil price and changes in inflation in Algeria, Angola, Libya, and Nigeria for the period 1995 to 2014. They employed Autoregressive distributed lags (ARDL) dynamic panel and result shows that there is positive and significant relationship between money supply, the exchange rate, gross domestic product (GDP) and inflation, while food production shows a negative and significant impact on inflation. Salisu, Isah, Oyewole and Akanni (2017) investigate the impact of non-linear relationship between oil price and inflation in oil exporting and importing countries with quarterly data for the period of 2000 to 2014 . They employed dynamic heterogenous panel data models and the result shows that there is a significant relationship between the variables in the long run, while the short run result produces a mixed result. However, it is shown that, oil price brings to bear a larger impact on inflation of net oil importing countries than their oil exporting equivalents

Similarly, Sangyup, Prakash, Saurabh and Marcos (2018) analyzes how instabilities in the international oil prices affect national inflation by employing an unbalanced panel data covering 72 developed and emerging economies for the period from 1970 to 2015. The result shows that there is a positive and significant impact of international oil prices on national inflation for these countries. This impact lingers for two years and vanished afterwards. The impact is similar for both developed and emerging economies. However, this relationship and impact is non-linear with positive impact having a larger effect than the negative impact. Also, Carola (2018) examine the dynamics of consumers' gas price and inflation expectations using data from the Michigan Survey of Consumers (MSC). Employing Panel Analysis, the findings revealed that, consumers on average view gas price inflation as negatively correlated and they do expect gas price inflation to feed into future core inflation, but this quickly decreases with forecast horizon.

Asghar and Naveed (2015) investigate long-run pass through of world oil prices to domestic inflation in Pakistan from January 2000 to December 2014 using Autoregressive Distributed Lag (ARDL) bounds testing approach and Granger causality. They found that in the long-run international oil prices and exchange rate significantly affect the inflation rate in Pakistan. 
Furthermore, oil price (LOILP) has positive relationship with inflation and Nominal Exchange Rate (LER) has negative relationship with inflation rate in Pakistan. The findings of the Granger causality test reveal that there is unidirectional causality that runs from world oil prices to inflation rate, from inflation to exchange rate, and from world oil prices to exchange rate in Pakistan. Also, Husaini, Puah and Lean (2019) investigate the empirical evidence concerning the relationship between the international oil price and energy subsidy, and price behavior. Using time series data covering the period 1981-2015, they employed the autoregressive distribution lag (ARDL) approach which revealed that factors, oil price and energy subsidy, are significant in influencing the pattern of price behavior. The PPI (Producer Price Index) was more sensitive to changes in the oil price than the CPI (Consumer Price Index). The PPI was found to be affected more while the CPI was less affected.

Hammoudeh and Reboredo (2018) examine the link between oil prices and market-based inflation expectations in the United States. Using data for both the 5-year and the 10-year breakeven inflation proxies for medium-term and long-term market-based inflation rates as given by the difference between yields on nominal Treasuries and TIPS for the two maturities for the USA and employing linear ARDL model, the study found that the impact of oil price changes on inflation expectations is more intense when oil prices are above a threshold of 67 USD per barrel and is more pervasive for the intermediate term than for the longer term. Shaari, Yusuf, Abashah and Pei (2018) investigate the effects of retail selling prices of petrol and diesel on inflation in Malaysia using monthly data from 2010 to 2015. An Autoregressive distributed lag approach (ARDL) results shows that there are significant effects of retail selling prices of petrol and diesel in the long run.

Likewise, using linear and non-linear ARDL, Kun (2017) examine the linear and non-linear passthrough impact of oil price variations on four national price directories in Malaysia using Annual data from the years 1980 to 2015. The study employed ARDL and NARDL models and the result shows evidence of linear and non-linear pass-through impact of oil price variations on national prices athwart sectors. Oil price variations have positive on the growth in output which in turn influence increase in commodity prices, while oil price variations have a partial direct impact on consumer prices in the long run. Also, Lacheheb and Sirag (2019) captures asymmetries association among oil price and inflation in Algeria for the period of 1970-2014 using NARDL. The findings show that there is an asymmetric relationship between oil price and inflation as well as a significant impact.

Frédérique and Annabelle (2016) empirically investigate the implication of oil price forecast errors on inflation forecast errors for the United States, France and United Kingdom for the period of 2005q1-2013q. The study employed threshold nonlinear model and found that, oil price forecast contribute positively and significantly the behavior of inflation forecast errors in all the countries. Specifically, the oil price forecast errors has a double impact on the inflation expectation forecast error. Abu-Bakar and Masih (2018) investigate whether the oil price passthrough to domestic inflation symmetric or asymmetric India. Using monthly data from 1994 to 2018. Autoregressive distributed lag approach (ARDL) and Nonlinear autoregressive distributed lag approach (NARDL) results revealed that an increase in oil price have a significant impact on the increase in inflation, while decrease in oil price does not have significant impact on inflation for the period of study. However, the ARDL result produced a contradicting result of no long run relationship between oil price and inflation as compared to NARDL result.

Jiranyakul (2018) examine the effect of oil price shocks on the local inflation rate in Thailand using monthly data from January1993 to December 2016. The study employed symmetric and asymmetric cointegration tests with structural breaks and the result depicts that, industrial output and oil price have significant and positive impact on inflation in the country both in the 
short and long run. Lacheheb and Sirag (2019) examine the association between oil price and inflation in Algeria using annual data from 1970 to 2014. Using a nonlinear autoregressive distributed lags (NARDL) model, the result shows the presence of a non-linear relationship between oil price and inflation both the long run and in the short run. However, the long run impact seems to be greater than the short run impact.

Likewise, Nasir, Naidoo, Shahbaz and Amoo (2018) examines the consequences of oil prices blows on the BRICS economies for the period of 1987QII - 2017QII. Employing a time-varying structural vector autoregressive (TV-SVA) framework, the study reveals that each countries responded differently in terms of direction and magnitude to the shocks in crude oil prices, while such relationship is also non-linear in nature between countries exporting and those importing oil.

\section{Methodology}

\section{Theoretical Framework}

The monetarists argue that excess money supply is the cause of inflation. According to them, if more money is supplied than what people want, they will have to get rid of the excess and this is the cause of inflation. In countries where there is high money supply, inflation also tends to be high. The monetarists therefore argue that inflation is a monetary phenomenon. Monetarists focus on fiscal deficit, money creation and inflation while the new structuralists emphasize the link between full bottlenecks, income distribution and social conflict over the determination of real wages (Agenor \& Montiel, 1996).

Mathematically,

$$
\text { Inflation }=f\left(M^{s}-M^{d}\right)
$$

If the result of equation 3.1 is positive, then there is excess supply of money.

In the money market,

$$
\begin{gathered}
\frac{M}{P}=f(i, y) \ldots \\
p=\frac{M}{f(i, y)} . \\
\text { But } \frac{1}{f(i, y)}=k \ldots \ldots
\end{gathered}
$$

Where $\mathrm{k}$ is a constant

$$
P=k M \text {. }
$$

Where $\mathrm{P}$ is price and $\mathrm{M}$ is money supply.

According to the monetarists, in the long-run inflation is explained solely by monetary supply as shown in equation 4.5 .

Fisher examined the link between the total quantity of money (money supply) and the total amount of spending in final goods and services produced in an economy $(P \times Y)$, where $\mathrm{P}$ is the price level and $Y$ is the aggregate output or income). Accordingly, the concept that provides the link between money supply $(\mathrm{M})$ and $(P \times Y)$, is velocity of money $(\mathrm{V})$. Mishkin (2007).

$$
v=\frac{P \times Y}{M}
$$

He obtained the equation of exchange by multiplying both sides of the equation 3.6a by M.

$$
M \times V=P \times Y
$$


The quantity theory of money was derived from the equation of exchange based on Fisher's view that velocity is fairly constant. According to the classical economists, the quantity theory of money explains that the movements in the price level result solely from the quantity of money.

Quantity equation is therefore the same as: $M \times V=P \times Y$

Where; $\mathrm{M}$ is Money; $\mathrm{V}$ is Velocity; $\mathrm{P}$ is price and $\mathrm{Y}$ is output

\section{Model Specification}

The main objective of the study is to assess the impact of oil price changes on inflation using monthly data from the period of 1991 to first quarter of 2019. Therefore, oil price change is the key explanatory variable in the model specified following Sek (2017) whose model was adapted in this study, and oil price among other variables, is expected to have an influence on the dependent variable (inflation). Inflation is measured by the consumer price index (CPI). The CPI is chosen since it is the best measure for adjusting payments to consumers when the intent is to allow consumers to purchase, at today's prices, a market basket of goods and services equivalent to the one that they could have purchased in an earlier period. It is also the best measure to use when one wants to translate retail sales and hourly or weekly earnings into real or inflation-free figures. The interest rate and exchange rate may also affect the inflation rate (cpi), Therefore, in addition to the oil price change (oilp), interest rate change (intr) and the exchange rate change (exr) are included as independent variables. The model is formulated as thus;

inf $=f($ oilprice, intr, exr $)$

Equation 3.7 can be transformed into econometrics model as;

$\inf _{t}=\beta_{0}+\beta_{1}$ oilp $_{t}+\beta_{2}$ intr $_{t}+\beta_{3} \operatorname{exr}_{t}+\mu$

Where;

$\mu$ is the error term.

\section{Estimation Techniques}

\section{Methodology}

The study applies linear autoregressive distributed lag (ARDL) models, which enable interpretation based on the short- and long-run effects of the explanatory variables on the dependent variable. The linear ARDL model is the conventional co-integration approach, as applied in Pesaran and Shin (1999), and has a few advantages over the other co-integration techniques. First, this model performs better in modeling the co-integrating relationship with small samples (Romilley et al., 2001; Pesaran et al., 1997). Second, this model can be applied when there is a mixture of regressors' order integrated with $\mathrm{I}(0)$ or $\mathrm{I}(1)$, which is not possible under alternative co-integration models. However, this model is not valid when there are I(2) variables.

The analyses involve several steps. First, unit root tests are carried out to check the stationarity of variables. Because the ARDL model requires that all variables must at most be integrated of order one, this step helps to ensure that there is no variable with $\mathrm{I}(2)$ or larger but that combinations of $\mathrm{I}(0)$ and $\mathrm{I}(1)$ variables are possible. In the second step, the ARDL model is constructed to specifications (optimal lag lengths) based on the Schwarz information criterion (SIC). This step is followed by bounds testing to check for a co-integrating relationship between the dependent and the explanatory variables. If a long-run relationship is detected, then the estimation on the ARDL model is valid. If no long-run relationship is detected, an alternative model should be applied. The final step involves diagnostic tests (ARCH and LM tests) to check the autocorrelation of residuals with the good fit of the model. 
The conventional linear ARDL $(p, q)$ model is as constructed by Pesaran et al. (1999) which can be written in the following way:

$$
y_{t}=\sum_{i=1}^{p} \lambda_{i} y_{t-j}+\sum_{i=0}^{q} \delta^{\prime}{ }_{i} x_{t-i}+\varepsilon_{t}
$$

where $y_{t}$ is the dependent variable; $x_{t}$ is a $k \times 1$ coefficient vectors for exogenous variables; exogenous variables; $\lambda_{i}$ is the vector of scalars and $\varepsilon_{t}$ is a disturbance term with mean zero and a finite variance. This equation can be written in an error correction format:

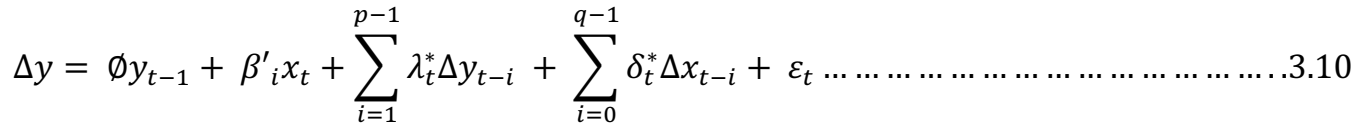

$$
\begin{aligned}
& \Delta i n f_{t}^{s}=\operatorname{con}+\sum_{i=1}^{p} a_{i} \Delta i n f_{t-i}^{s}+\sum_{i=0}^{q_{1}} b_{i} \Delta o i l p_{t-i}^{s}+\sum_{i=0}^{q_{2}} c_{i} \Delta i n t r_{t-i}^{s}+\sum_{i=0}^{q_{3}} d_{i} \Delta e x r_{t-i}^{s}+\alpha_{1} i n f_{t-i}^{s} \\
& +\alpha_{2} \text { oilp } p_{t-i}^{s}+\alpha_{3} \text { intr }_{t-i}^{s}+\alpha_{4} \text { exr }_{t-i}^{s}+e_{t}
\end{aligned}
$$

Where

$$
\begin{aligned}
& \emptyset=-1\left(1-\sum_{j=1}^{p} \lambda_{j}\right) ; \beta_{i}=\sum_{i=0}^{q} \delta_{i} ; \lambda_{i}^{*}=\sum_{m=i+1}^{q} \lambda_{m} ; i=1,2, \ldots, p-1 ; \delta_{t}^{*}=\sum_{m=i+1}^{q} \delta_{m}, i \\
& =1,2, \ldots q-1
\end{aligned}
$$

The error correction of equation 3.12 can be regrouped and summarized as;

$$
\Delta y_{t}=\varnothing\left(y_{t-1}-\theta_{i}^{\prime} x_{t}\right)+\sum_{i=1}^{p-1} \lambda_{i} \Delta y_{t-i} \sum_{i=0}^{q-1} \delta_{t}^{*} \Delta x_{t-i}+\varepsilon_{t}
$$

$\theta=-\left(\frac{\beta}{\phi}\right)$ indicates the long-run or equilibrium relationship among $y_{t}$ and $x_{t} \cdot \lambda_{i}^{*}$ and $\delta_{i}^{*}$ are the short-run coefficients for lagged terms of changes in $y_{t}$ and $x_{t}$ respectively. $\varnothing$ is the errorcorrection coefficient indicating the speed of adjustment of $y_{t}$ in converging to its long-run equilibrium as $x_{t}$ changes. This parameter always takes the negative value to ensure convergence in the long-run relationship.

\section{Analysis and Interpretation of Result}

\section{Data Presentation}

The monthly data on Inflation Rate, Oil Price, Exchange Rate and Interest Rate from 1990 to 2019:1 are presented in table 1 in the appendix.

\section{Descriptive Analysis}

Table 1: Descriptive Analysis Result

\begin{tabular}{|l|c|c|c|c|}
\hline & INF & OILP & EXR & INTR \\
\hline Mean & 97.62264 & 55.96045 & 167.5381 & 9.975616 \\
\hline Median & 75.18500 & 50.48500 & 140.8450 & 9.360000 \\
\hline Maximum & 283.4600 & 138.7400 & 494.7000 & 18.09000 \\
\hline
\end{tabular}




\begin{tabular}{|l|c|c|c|c|}
\hline Minimum & 14.36000 & 10.22000 & 77.15000 & 3.490000 \\
\hline Std. Dev. & 71.65392 & 34.06748 & 90.07823 & 2.947520 \\
\hline Skewness & 0.917561 & 0.544596 & 1.749683 & 0.188588 \\
\hline Kurtosis & 2.850093 & 2.112977 & 5.198923 & 2.983056 \\
\hline & & & & \\
\hline Jarque-Bera & 41.24674 & 24.00662 & 207.8168 & 1.734340 \\
\hline Probability & 0.000000 & 0.000006 & 0.000000 & 0.420139 \\
\hline & & & & 2980 \\
\hline Sum & 28505.81 & 16340.45 & 48921.13 & 2912.880 \\
\hline Sum Sq. Dev. & 1494077. & 337732.6 & 2361200. & 2528.172 \\
\hline & & & & 292 \\
\hline Observations & 292 & 292 & & 292 \\
\hline
\end{tabular}

Table 4.1.1 shows the descriptive statistics of INFR, OILP, EXR and INTR. It is shown that all the variables under consideration contained 292 observations. EXR has the highest mean value followed by INFR, OILP and INTR respectively. The table also revealed that only EXR is mesokurtic as its value is greater than three, while others are platykurtic given that their kurtosis values are less than three. The probability of the Jarque-Bera shows that all the variables except INTR are not normally distributed as their probability values do not pass normality test at $1 \%$, $5 \%$ and $10 \%$.

\section{Unit Root Test}

Following the descriptive statistics is the unit root test to examine stationarity properties of the variables used in the model. We applied Philip Peron (PP) and ADF tests and the results are presented in table 1:

Table 2: Unit Root Test Result

\begin{tabular}{|l|l|l|l|l|l|l|l|l|l|}
\hline \multicolumn{9}{|c|}{ Phillip-Perron Unit-Root Test Statistics (At Level) } \\
\hline \multirow{2}{*}{ Variables } & \multicolumn{3}{|c|}{ With Constant } & \multicolumn{2}{|c|}{ With Constant \& Trend } & \multicolumn{2}{|c|}{$\begin{array}{l}\text { Without Constant \& } \\
\text { Trend }\end{array}$} \\
\hline & $\begin{array}{l}\text { t- } \\
\text { statistic }\end{array}$ & Prob. & Level & $\begin{array}{l}\text { t- } \\
\text { statistic }\end{array}$ & Prob. & Level & $\begin{array}{l}\text { t- } \\
\text { statistic }\end{array}$ & Prob. & Level \\
\hline INF & 10.1453 & 1.0000 & NS & -2.9258 & 0.1659 & NS & -1.0752 & 0.2943 & NS \\
\hline OILP & -1.8296 & 0.3657 & NS & -1.7907 & 0.6900 & NS & -0.9624 & 0.2943 & NS \\
\hline
\end{tabular}


Journal of Management and Economic Studies, vol.3, issue.3, pp.84-101

\begin{tabular}{|c|c|c|c|c|c|c|c|c|c|}
\hline EXR & -0.3185 & 0.9190 & NS & -1.7690 & 0.7004 & NS & -0.2401 & 0.5933 & NS \\
\hline INTR & -2.9872 & 0.0373 & $\mathrm{I}(1)$ & -3.3437 & 0.0614 & $\mathrm{I}(1)$ & -1.0243 & 0.2748 & NS \\
\hline \multicolumn{10}{|c|}{ Phillip-Perron Unit-Root Test Statistics (At First Difference) } \\
\hline & $\begin{array}{l}\mathbf{t}- \\
\text { statistic }\end{array}$ & Prob. & Level & $\begin{array}{l}\mathrm{t}- \\
\text { statistic }\end{array}$ & Prob. & Level & $\begin{array}{l}\mathrm{t}- \\
\text { statistic }\end{array}$ & Prob. & Level \\
\hline INF & -9.5904 & 0.0000 & $\mathrm{I}(1)$ & -11.1383 & 0.0000 & $\mathrm{I}(1)$ & -6.5203 & 0.0000 & $\mathrm{I}(1)$ \\
\hline OILP & -12.0669 & 0.0000 & $\mathrm{I}(1)$ & -12.0497 & 0.0000 & $\mathrm{I}(1)$ & -12.0745 & 0.0000 & $\mathrm{I}(1)$ \\
\hline EXR & -12.7344 & 0.0000 & $\mathrm{I}(1)$ & -12.7339 & 0.0000 & $\mathrm{I}(1)$ & -12.7012 & 0.0000 & $\mathrm{I}(1)$ \\
\hline INTR & -21.0443 & 0.0000 & $\mathrm{I}(1)$ & -21.0443 & 0.0000 & $\mathrm{I}(1)$ & -21.0998 & 0.0000 & $\mathrm{I}(1)$ \\
\hline \multicolumn{10}{|c|}{ Augmented Dickely Fuller (ADF) Unit-Root Test Statistics (At Level) } \\
\hline \multirow[t]{2}{*}{ Variables } & \multicolumn{3}{|c|}{ With Constant } & \multicolumn{3}{|c|}{ With Constant \& Trend } & \multicolumn{3}{|c|}{$\begin{array}{c}\text { Without Constant \& } \\
\text { Trend }\end{array}$} \\
\hline & $\begin{array}{l}\mathbf{t}- \\
\text { statistic }\end{array}$ & Prob. & Level & $\begin{array}{l}\mathrm{t}- \\
\text { statistic }\end{array}$ & Prob. & Level & $\begin{array}{l}\text { t- } \\
\text { statistic }\end{array}$ & Prob. & Level \\
\hline INF & -7.0138 & 1.0000 & NS & -4.9973 & 0.7116 & NS & -1.1282 & 0.2312 & NS \\
\hline OILP & -1.9565 & 0.3622 & NS & -1.7103 & 0.7276 & NS & -0.9624 & 0.2943 & NS \\
\hline EXR & -0.4920 & 0.8893 & NS & -1.7367 & 0.7156 & NS & -0.2401 & 0.5933 & NS \\
\hline INTR & -2.3769 & 0.1492 & NS & -2.5582 & 0.3000 & NS & -0.9633 & 0.2993 & NS \\
\hline \multicolumn{10}{|c|}{ Augmented Dickely Fuller (ADF) Unit-Root Test Statistics (At First Difference) } \\
\hline & $\begin{array}{l}\mathrm{t}- \\
\text { statistic }\end{array}$ & Prob. & Level & $\begin{array}{l}\mathrm{t}- \\
\text { statistic }\end{array}$ & Prob. & Level & $\begin{array}{l}\text { t- } \\
\text { statistic }\end{array}$ & Prob. & Level \\
\hline INF & -0.6941 & 0.8451 & NS & -11.0867 & 0.0000 & $\mathrm{I}(1)$ & -0.2569 & 0.7599 & $\mathrm{I}(1)$ \\
\hline OILP & -12.0669 & 0.0000 & $\mathrm{I}(1)$ & -12.0497 & 0.0000 & $\mathrm{I}(1)$ & -12.0745 & 0.0000 & $\mathrm{I}(1)$ \\
\hline EXR & -4.7426 & 0.0001 & $\mathrm{I}(1)$ & -4.8169 & 0.0005 & $\mathrm{I}(1)$ & -4.5931 & 0.0000 & $\mathrm{I}(1)$ \\
\hline INTR & -21.4877 & 0.0000 & $\mathrm{I}(1)$ & -21.4532 & 0.0000 & $\mathrm{I}(1)$ & -21.5189 & 0.0000 & $\mathrm{I}(1)$ \\
\hline
\end{tabular}

Source: Author's Computation from E-Views 10.0, 2019.

The test result indicates that all variables are not stationary at levels but stationary at first differences (results are reported in Table 1). It shows that the hypotheses of unit root are rejected for individual variables at $1 \%$ level of significance in their first difference. Hence, all the variables 
are said to be integrated of same I(1) order except the interest rate that is stationary at level under Phillip-Peron test in the cases of with constant and with trend. Therefore, the next step is to investigate short-run and long-run relationship among the variables using the autoregressive distributed lag model method.

\section{Lag selection criteria}

The information criterion presented in table 4.4 showed that ARDL $(1,1,00)$ is appropriate for the model in this study. This explains the advantage of ARDL methodology as it is not necessary for all the variables to have the same lag(s) contrary to that of VAR which all variables are given the same lag(s). The optimal lag selection must be considered as this may result to the problem of misspecification and autocorrelation if ignored.

\section{Akaike Information Criteria (top 20 models)}

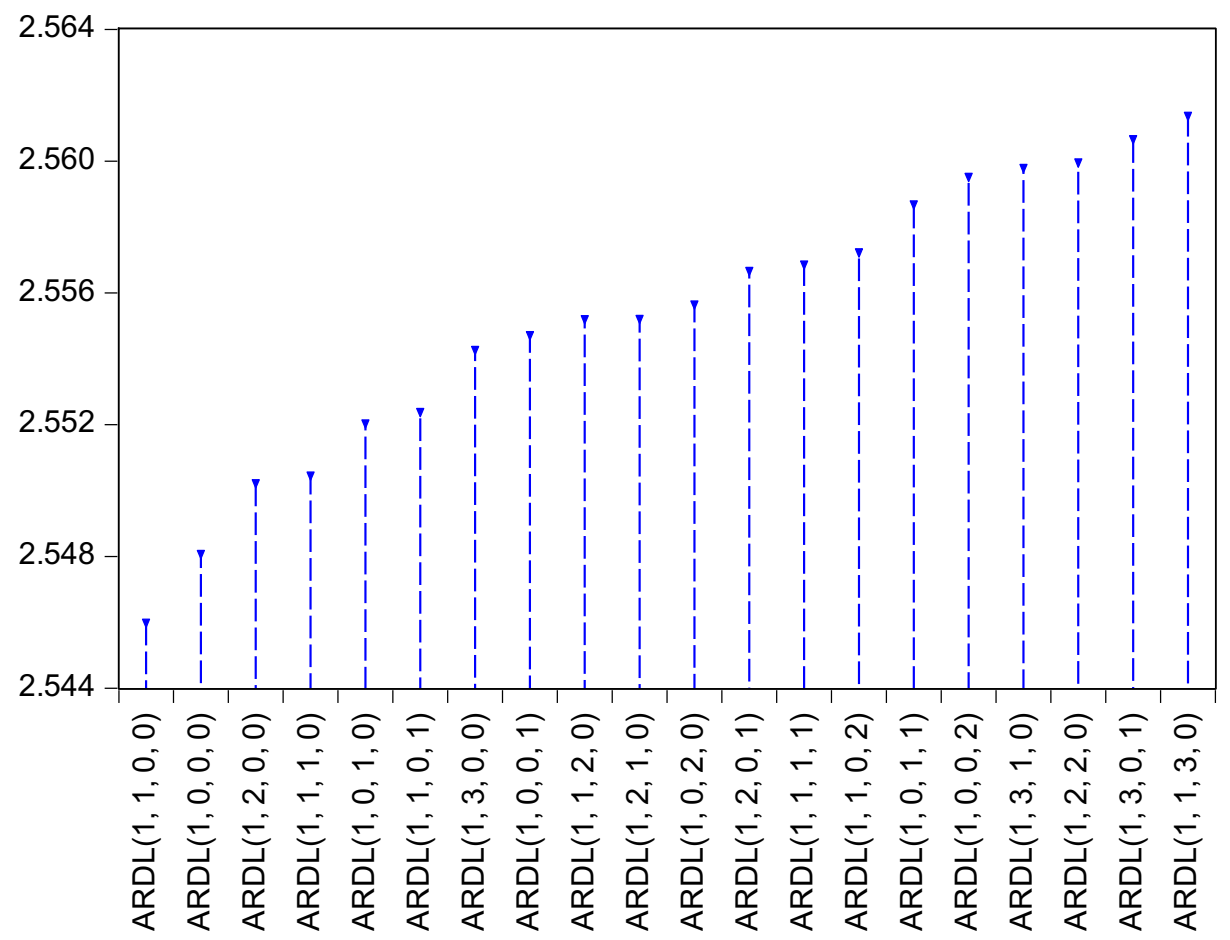

Figure 4.2.1: Lag selection criteria

\subsubsection{Estimated Long Run Model}

Here, the model on impact of oil price on inflation rate in Nigeria is estimated using ARDL model and the result is presented in the table 4.2.2; 
Table 4.2.2 Estimated Long Run Coefficients Using the ARDL Approach

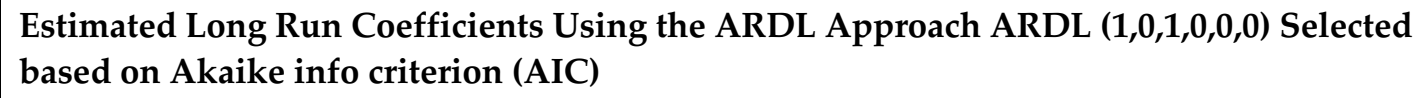



Source: Author's computation Obtained from E-views 10)

Note: ${ }^{* *}$ and ${ }^{*}$ indicate significance at $1 \%$ and $5 \%$ level of significances. Figures in parenthesis are probability values. A is Breusch-Godfrey Serial Correlation LM Test, B is Ramsey's RESET test, $\mathrm{C}$ is Normality Test, D is Heteroscedasticity test.

The result presented in table 4.2.2 shows the estimated long run model of the impact of oil price on inflation rate in Nigeria. The one period lag of dependent variable shows a positive and significant relationship with its current value, while oil price and exchange rate also show positive and negative relationships with the dependent variable respectively. A unit increase in the one lag period of inflation rate leads to 1.000606 units increase in its current value. A unit increase in oil price leads to 0.018341 units decrease in the inflation rate, while a unit increase exchange rate is associated with 0.006982 units increase in the target variable.

In the same vein, the coefficient of determination $\left(\mathrm{R}^{2}\right)$ shows that $99 \%$ of the variations in the economic growth is explained by the explanatory variables which is above $50 \%$ and even after 
taking into consideration the degree of freedom, the adjusted coefficient of determination (adjusted $\mathrm{R}^{2}$ ) still shows that, 99\% variation in the economic growth is explained by the explanatory variables. The F-statistic $408469.5(0.00000)$ confirmed the fitness of the coefficient of determination and shows an overall significant level of the explanatory variables jointly in explaining economic growth.

Also, the outcome of this result can be tested using some diagnostic tests such Breusch-Godfrey Serial Correlation LM Test, Ramsey's RESET test, Normality Test and Heteroscedasticity test. The result of these tests as presented in table 4.2.2 shows that, the model passes all the diagnostic tests. The diagnostic tests applied to the model point out that there is no evidence of serial correlation and heteroscedasticity. Besides, the RESET test implies the correctly specified ARDL model and the skewness and kurtosis of residuals, but the normality test shows that the residuals are not normally distributed.

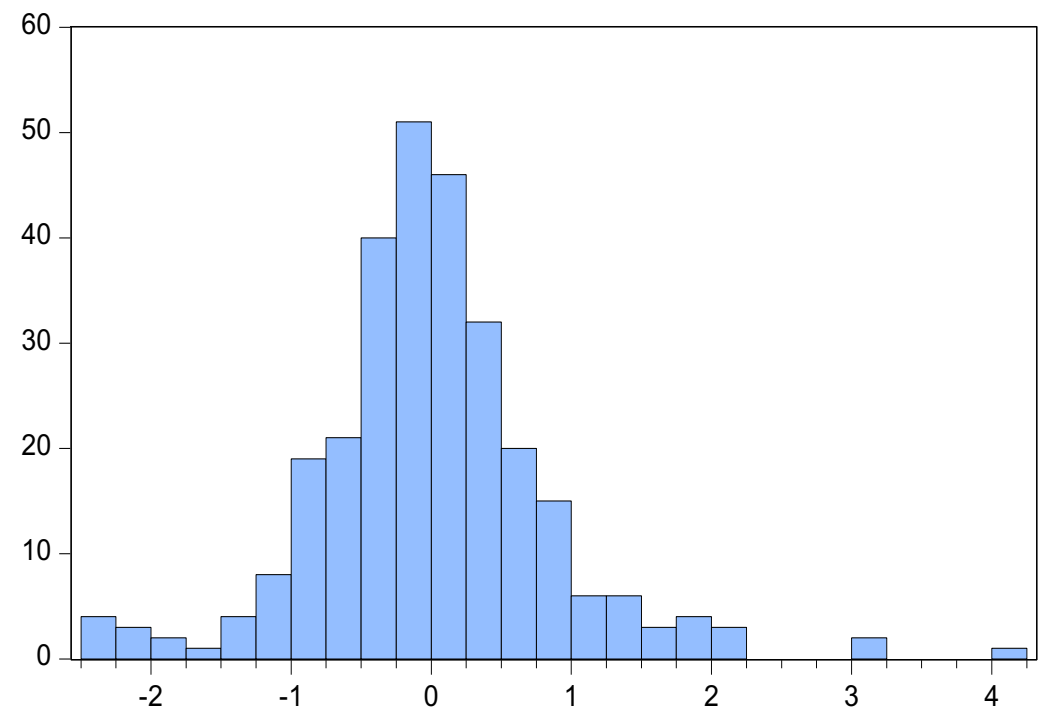

\begin{tabular}{|c|c|}
\hline $\begin{array}{l}\text { Series: Resi } \\
\text { Sample } 199 \\
\text { Observation }\end{array}$ & $\begin{array}{l}\text { uals } \\
\text { h02 2019M04 } \\
291\end{array}$ \\
\hline Mean & $1.85 \mathrm{e}-14$ \\
\hline Median & -0.051017 \\
\hline Maximum & 4.093033 \\
\hline Minimum & -2.497249 \\
\hline Std. Dev. & 0.845866 \\
\hline Skewness & 0.507886 \\
\hline Kurtosis & 6.097193 \\
\hline Jarque-Bera & 128.8209 \\
\hline Probability & 0.000000 \\
\hline
\end{tabular}

Figure 4.2.1(A): Normality Test

The stability of the regression coefficients is tested using the cumulative sum (CUSUM) of the recursive residual test for structural stability. Plots of the CUSUM shows that the regression equation seems stable given that the CUSUM test statistics does not go beyond the bounds of the $5 \%$ level of significance.

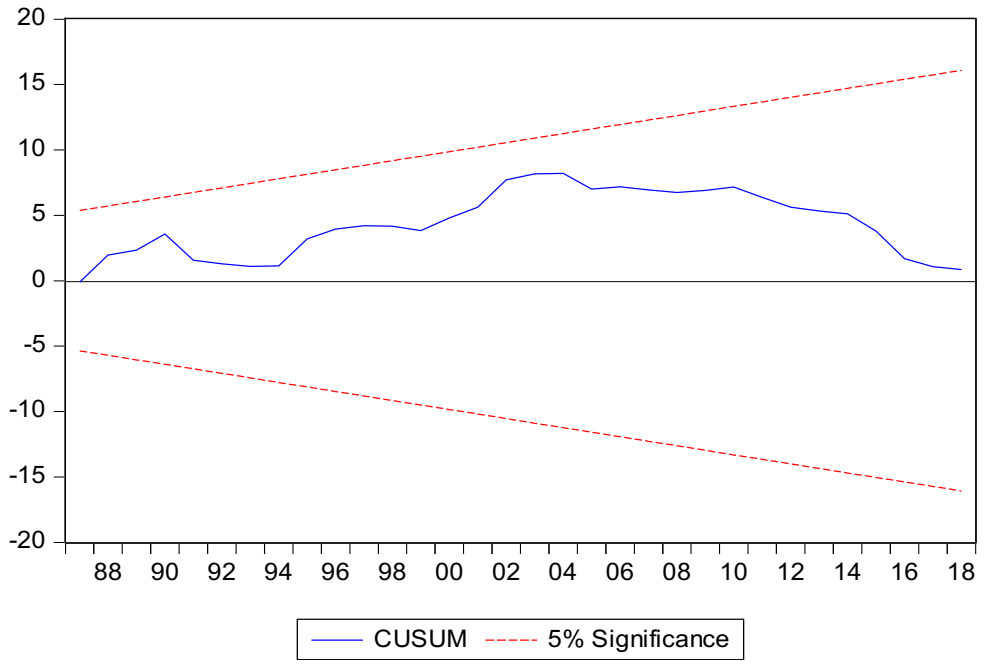

Figure 4.2.1(B): Stability (CUSUM) Test 


\section{ARDL Bound Test Approach to Cointegration}

The bound test approach to cointegration seeks to confirm if there is long run relationship among the variables in the model. This is done by testing if their coefficients are equal to zero in our estimated model or not. The F-Statistic value from the bound test and the critical value bounds as revealed by the result given by E-views 10 is presented in the table 4.2.3;

Table 4.2.3: ARDL Bounds Test Result

\section{Null Hypothesis: No long-run relationships exist}

\begin{tabular}{|l|c|c|l|l|}
\hline \hline Test Statistic & Value & K & & \\
\hline \hline F-statistic & 5.541898 & 5 & & \\
\hline Critical Value Bounds & & & \\
\hline Significance & I0 Bound & I1 Bound & & \\
\hline \hline $10 \%$ & 2.08 & 3 & & \\
\hline $5 \%$ & 2.39 & 3.38 & & \\
\hline $2.5 \%$ & 2.70 & 3.73 & & \\
\hline $1 \%$ & 3.06 & 4.15 & & \\
\hline
\end{tabular}

Source: Author's computation Obtained from E-views 10)

ARDL bounds $F$ test results as reported in Table 4.2.3 shows that the result confirms the presence of a long run relationship between inflation rate and the independent variables in the model for the period under consideration in Nigeria. This is because the calculated F statistic is 5.541898 greater than upper critical values at $1 \%, 5 \%$ and $10 \%$ significance level, and thus, inferring that there exists a co-integrating relationship among the time series in the level form, without considering whether they are I(0) or I(1).In other words, the Null hypothesis of no cointegration can be rejected at the $1 \%, 5 \%$ and $10 \%$ significance levels because $\mathrm{F}$ test statistic is greater than the critical upper bounds value I(1).

\section{Short Run Dynamics and Error Correction Representation of ARDL Cointegrating}

After confirming the existence of a long-run relationship among the and foreign aid variables in the study, it is pertinent to estimate both the error correction mechanism form of the model together with its long run form. Error correction model was first used by Sargan (1964) and after this popularized by Engle and Granger (1987).

Also, the diagnostic tests were examined from the unrestricted error correction (bounds test) model. These include Lagrange multiplier test of residual serial correlation, Ramsey's RESET test using the square of the fitted values for correct functional form (no mis-specification), JarqueBera normality test based on the skewness and kurtosis measures of the residuals and Breusch- 
Godfrey heteroscedasticity test based on the regression of squared residuals on the original regressors of the model. The results are presented in the table 4.2.4;

Table 4.2.4 Estimated Short Run Dynamics and Error Correction

Representation of ARDL $(1,1,0,0)$ Selected based on Akaike info criterion (AIC)

Dependent variable is INFR

\begin{tabular}{|l|r|r|r|r|}
\hline \multicolumn{1}{|c|}{ Regressor } & \multicolumn{1}{c|}{ Coefficient } & \multicolumn{1}{c|}{ Std. Error } & \multicolumn{1}{c|}{ t-Statistic } & \multicolumn{1}{c|}{ Prob. $^{*}$} \\
\hline D(OILP) & 0.018341 & 0.009603 & 1.910059 & $0.0571^{*}$ \\
\hline CointEq(-1) & -0.441904 & 0.095069 & -4.648240 & $0.0000^{* * *}$ \\
\hline Diagnostic Tests & LM Version \\
\hline Test Statistics & $X^{2}$ auto $=12.95877(0.4620)$ \\
\hline A. Serial Correlation & $X^{2}$ RESET $=0.095186(0.0 .7579)$ \\
B. Functional Form (Ramsey Reset) & $X^{2}$ Norm $=128.8209(0.00000)$ \\
C. Normality & $X^{2}$ Het $=3.468712(0.1146)$ \\
D. Heteroscedasticity &
\end{tabular}

Source: Author's computation Obtained from E-views 10)

Note: ${ }^{* *}$ and ${ }^{*}$ indicate significance at $1 \%$ and $5 \%$ level of significances. Figures in parenthesis are probability values. A is Breusch-Godfrey Serial Correlation LM Test, B is Ramsey's RESET test, $\mathrm{C}$ is Normality Test, $\mathrm{D}$ is Heteroscedasticity test.

The result presented in table 4.2.4 suggests that the effect of first difference of oil price on inflation rate is positive and significant. The variables have the lags of 1,1 except exchange rate and interest rate that assume the lag 0,0 respectively from the selected model: ARDL $(1,1,0,0)$, this means the effect of interest rate and exchange rate are instantaneous, while that of oil price and dependent variable are not i.e the dynamic responses are being controlled by the lag dependent variable. In other words, the dynamic response of dependent variable to these variables' shock, are being controlled by their contemporaneous values. Hence, the short run parameter is equivalent to the instantaneous parameter in the original ARDL result. Furthermore, the magnitude of the estimated coefficient of the error correction term suggests a relatively moderate speed of adjustment to any disequilibrium in the short run. In other words, the estimated ECMt1 is equal to 0.441904 which states that the departure from the equilibrium is adjusted by $44 \%$ per year. It is also negative, significant and less than one which means that information from this can be relied upon for policy decisions.

\section{Conclusion and Recommendation}

The study has attempted an examination of the relationship between oil price and inflation rate in Nigeria both in the long-run and short run. The results presented evidently suggest that in the long run, oil price exerts positive influence on the rate of inflation in Nigeria over the time; as oil price increases, inflation rate does increase. Also the exchange rate as part of the control variables and the lag value of the dependent variable exert positive influences on the target variable. In the 
short run, oil price also shows a positive relationship with the inflation rate which is in accordance with the long run result. It is therefore recommended that, curbing the increasing erratic inflation rate as a cankerworm that eats the fabric of prosperity of an economy could be done by paying good attention to the swinging nature of oil price as well as exchange rate and taking proactive actions in manipulating monetary policy tools to cushion any negative effect as a result of their outcomes in the economy.

\section{References}

Abu-Bakar, M., \& Masih, M. (2018). Is the oil price pass-through to domestic inflation symmetric or asymmetric? new evidence from India based on NARDL.

Afees A. Salisu, Kazeem O. Isah, Oluwatomisin J. Oyewole, Lateef O. Akanni, (2017), Modelling oil price-inflation nexus: The role of asymmetries, Energy doi: 10.1016/j.energy.2017.02.128.

Al-Eitana, G. N., \& Al-Zeaudb, H. A. Impact of Fluctuations in the Prices of Crude Oil on Inflation: Evidence from Jordanian Economy.

Agenor, P.R and Montiel, P.J. (1996), Development Macroeconomics, Princeton, NJ: Princeton University Press

ALsaedi, R. N. (2015). The Relationship between Oil Prices, Inflation, Exchange Rate and Economic Activities: Cases GCC between 2010 to 2014. International Journal of Sciences: Basic and Applied Research.

ALsaedi, R. N. The Relationship between Oil Prices, Inflation, Exchange Rate and Economic Activities: Cases GCC between 2010 to 2014.

Anwar, M. M., Khan, G. Y., \& Khan, S. J. I. Effect of increase in oil price on inflation in pakistan.

Asghar, N., \& Naveed, T. A. (2015). Pass-Through of World Oil Prices to Inflation: A Time Series Analysis of Pakistan. Pakistan Economic and Social Review, 269-284.

Asghar, N., \& Naveed, T. A. (2015). Pass-Through of World Oil Prices to Inflation: A Time Series Analysis of Pakistan. Pakistan Economic and Social Review, 269-284.

Bala, U., \& Chin, L. (2018). Asymmetric Impacts of Oil Price on Inflation: An Empirical Study of African OPEC Member Countries. Energies, 11(11), 3017.

Bhattacharya, K., \& Bhattacharyya, I. (2001). Impact of increase in oil prices on inflation and output in India. Economic and Political weekly, 4735-4741.

Carola, Conces Binder (2018), Inflation Expectations and the Price at the Pump, Journal of Macroeconomics (2018), doi: https://doi.org/10.1016/j.jmacro.2018.08.006.

Castro, C., Jiménez-Rodríguez, R., Poncela, P., \& Senra, E. (2017). A new look at oil price passthrough into inflation: evidence from disaggregated European data. Economia Politica, $34(1), 55-82$.

Cerra, V., Economic Modelling (2017). How can a strong currency or drop in oil prices raise inflation and the black market premium?

Conflitti, C., \& Luciani, M. (2017). Oil price pass-through into core inflation. Bank of Italy Occasional Paper, (405). 
Frédérique Bec a, Annabelle De Gaye (2015). How do oil price forecast errors impact inflation forecast errors? An empirical analysis from US, French and UK inflation forecasts

Husaini DH, Puah C-H, Lean HH, (2019). Energy subsidy and oil price fluctuation, and price behavior in Malaysia: A time series analysis, Energy (2019), doi: https://doi.org/10.1016/j.energy.2019.01.078.

Jiranyakul, K. (2018). Oil price shocks and domestic inflation in Thailand. Available at SSRN 2578836.

Kun Sek S, (2017). Impact of oil price changes on domestic price inflation at disaggregated levels: Evidence from linear and nonlinear ARDL modeling, Energy (2017), doi: 10.1016/j.energy.2017.03.152.

Lacheheb M, and Sirag A, (2019). Oil Price and Inflation in Algeria: A nonlinear ARDL approach, Quarterly Review of Economics and Finance (2019), https://doi.org/10.1016/j.qref.2018.12.003.

Lacheheb, M., \& Sirag, A. (2019). Oil price and inflation in Algeria: A nonlinear ARDL approach. The Quarterly Review of Economics and Finance.

López-Villavicencio, A. and Pourroy, M. (2019). Inflation target and (a)symmetries in the oil price pass-through to inflation, Energy Economics, https://doi.org/10.1016/j.eneco.2019.01.025

Malik, A. (2016). The Impact of Oil Price Changes on Inflation in Pakistan. International Journal of Energy Economics and Policy, 6(4), 727-737.

Muhammad Ali Nasir, Lutchmee Naidoo, Muhammad Shahbaz, Nii Amoo (2018), Implications of Oil Prices Shocks for the Major Emerging Economies: A Comparative Analysis of BRICS. Eneeco (2018), doi:10.1016/j.eneco.2018.09.023.

Mishkin, F.S (2007) The Economics of Money, Banking, and Financial Market, Columbia University Pearson International Edition (8th edition) Mondi

Pesaran, M.H. and Shin, Y. (1999). "An Autoregressive Distributed Lag Modelling Approach to Cointegration Analysis." Econometrics and Economic Theory in the 20th Century: The Ragnar Frisch Centennial Symposium, Strom, S. (ed.) Cambridge University Press.

Pesaran, H. M. and Pesaran, B. (1997) Microfit 4.0 (Oxford University Press).

P Romilly, H Song, X Liu (2001) Car ownership and use in Britain: a comparison of the empirical results of alternative cointegration estimation methods and forecasts Applied Economics, volume 33, p. 1803 - 1818

Rangasamy, L. (2017). The impact of petrol price movements on South African inflation. Journal of Energy in Southern Africa, 28(1), 120-132

Robert Engle and Clive Granger, (1987), Co-integration and Error Correction: Representation, Estimation, and Testing, Econometrica, 55, (2), 251-76

Runl O. (2011), "Nigeria is poor because of oil alternative view", publication of change Africa New work Africa Centre for Leadership Strategy and Development.

Sargan, J.D., 1964. Three-stage least-squares and full maximum likelihood estimates, Econometrica 32, 77 -81.

Sangyup Choi Davide Furceri, Prakash Loungani, Saurabh Mishra, Marcos Poplawski-Ribeiro (2018) 
Shaari, M. S., Yusuf, A. H., Abashah, A., \& Pei, T. L. (2018). Can Retail Selling Prices of Petrol and Diesel Trigger Inflation in Malaysia?. In MATEC Web of Conferences (Vol. 150, p. 05070). EDP Sciences.

Sibanda, K., Hove, P., \& Murwirapachena, G. (2015). Oil prices, exchange rates, and inflation expectations in South Africa. The International Business \& Economics Research Journal (Online), 14(4), 587.

Subhani, M. I., Hasan, S. K., Qavi, I., \& Osman, A. (2012). An investigation of granger causality between crude oil price and inflation in Pakistan. International Research Journal of Finance and Economics, 100, 168-174.

Živkov, D., Đurašković, J., \& Manić, S. (2019). How do oil price changes affect inflation in Central and Eastern European countries? A wavelet-based Markov switching approach. Baltic Journal of Economics, 19(1), 84-104.

Corrado, C.J. and Jordan, B. D. (2002). The Fundamentals of Investments Valuation and Management. 2nd ed USA, McGraw-Hill Companies Inc.

Apere, T. G. O. (2017). Crude Oil Price Fluctuation and Inflation In Nigeria. Advances in Social Sciences Research Journal, 4(3) 190- 200

Central Bank of Nigeria (2006) Annual Statement and Statement of Account, CBN Publications

Labys W.C. (2006), "Globalization, Oil Price Volatility, and the U.S. Economy”, Regional Research Institute, Natural Resource Economics Program, West Virginia University Morgantown, WV, 265066108

Mba-Afolabi, J. (1999) “The Oil Price of Hike Blunder”, Newswatch, January 18, pp. 8- 16.

Nwosu, C.P. (2009) "Import of Fuel Prices on Inflation: Evidences from Nigeria". Research Department, Central Bank of Nigeria, http://ssm.com/abstract $=1365820$

Bobai F.D. (2012), "An Analysis of the Relationship between Petroleum Prices and Inflation in Nigeria", International Journal of Business and Commerce, 1(12): 1-7.

Blanchard, O. J. and Galí, J. (2007). “The Macroeconomic Effects of Oil Price Shocks: Why are the 2000s so different from the 1970s?" University of Chicago Press. International Dimensions of Monetary Policy, pp. $373-421$.

Victor (Vic) Valcarcel and Mark Wohar, (2013), Changes in the oil price-inflation passthrough, Journal of Economics and Business, 68, (C), 24-42

Cara S. Lown \& Robert W. Rich, (1997). "Is there an inflation puzzle?," Economic Policy Review, Federal Reserve Bank of New York, issue Dec, pages 5177.Handle: RePEc:fip:fednep:y:1997:i:dec:p:51-77:n:v.3no.4 